\title{
Credit Supply and the Price of Housing*
}

\author{
Giovanni Favara \\ International Monetary Fund \\ SFI
}

\author{
Jean Imbs \\ Paris School of Economics \\ SFI, CEPR
}

October 2010

\begin{abstract}
We show that since 1994, branching deregulations in the U.S have significantly affected the supply of mortgage credit, and ultimately house prices. With deregulation, the number and volume of originated mortgage loans increase, while denial rates fall. But the deregulation has no effect on a placebo sample, formed of independent mortgage companies that should not be affected by the regulatory change. This sharpens the causal interpretation of our results. Deregulation boosts the supply of mortgage credit, which has significant end effects on house prices. We find evidence house prices rise with branching deregulation, particularly so in Metropolitan Areas where construction is inelastic for topographic reasons. There is also evidence the fall in house prices after 2006 is most pronounced in least regulated states. We document these results in a large sample of counties across the U.S. We also focus on a reduced cross-section formed by counties on each side of a state border, where a regression discontinuity approach is possible. Our conclusions are strengthened.
\end{abstract}

JEL Classification Numbers: G21, G10, G12

Keywords: Credit Constraints, Mortgage Market, House Prices, Bank Branching.

*For useful comments, we thank Catherine Casamatta, Stijn Claessens, John Driscoll, Jack Favilukis, Rafael Lalive, Thomas Philippon, Romain Ranciere, Tara Rice, Thierry Tressel, Philip Valta, and participants at seminars at the IMF, INSEE-CREST, the Federal Reserve Board, the St Louis Fed, the Universidad Nova de Lisboa, the Bank of England, the European Central Bank, Amsterdam Business School, the 2010 Mid West Macroeconomic Meetings, the 2010 Annual Conference of The Paul Woolley Centre at the LSE, and the 2010 EFA annual meetings. Chris Gibson provided valuable research assistance. Financial support from the National Center of Competence in Research "Financial Valuation and Risk Management" is gratefully acknowledged. The National Centers of Competence in Research (NCCR) are a research instrument of the Swiss National Science Foundation. All errors are our own. Favara: gfavara@imf.org; Imbs: jeanimbs@gmail.com. 


\section{Introduction}

Are asset prices affected by the supply of credit? The answer is key to the modeling choices that underpin virtually any asset pricing model. It is also central to understanding the market response to changes in the regulation of credit markets and financial intermediaries, a question of immediate topical interest. Restrictions to the supply of credit can influence asset prices via a demand effect, as fewer investors participate in financial markets, or via changes in the discount rate, as the risk profile of assets responds to market liquidity.

A causal link going from the supply of credit to asset prices is elusive, because of selfevident identification issues. The provision of credit is not an exogenous variable: it can depend on the price of assets, that may be used as collateral. Reverse causality is a rampant issue. So is potential omitted variables bias: there is every reason to expect asset prices and credit supply to respond to ongoing or expected economic conditions.

In this paper, we identify exogenous shifts in the supply of credit through changes in the market structure of credit, trace their effects on the size and standards of mortgage loans, and evaluate their end impact on house prices. Our identification strategy rests on regulatory changes to bank branching in the U.S. post-1994. Even though interstate banking (i.e., crossstate ownership of banks) was fully legal after the passage of the Interstate Banking and Branching Efficiency Act (IBBEA) of 1994, U.S. states retained the right to erect roadblocks to hamper interstate branching. For instance, states were allowed to put limits on banks' size and deposits, to forbid de novo branching, and to generally limit banks' ability to expand geographically across state borders.

Rice and Strahan (2010) have constructed a time-varying index capturing state-level differences in regulatory constraints to interstate branching. They show restrictions correlate with the political struggle between large (expansion-minded) banks and small (insulated) banks, but not with contemporaneous economic conditions. As a consequence, the index is arguably orthogonal to demand conditions in credit markets, and can be used as an instrument to trace the economic consequences of exogenous changes in the availability of credit. In this paper, we merge the Rice-Strahan index with county-level information on mortgage loans and house prices. Since the Rice-Strahan index runs from 1994 until 2005, we are able to inform recent developments in the U.S mortgage and housing markets.

Like Rice and Strahan (2010) and many others, we implement a conventional treatment effect estimation, where identification obtains across states and over time. We use this framework to answer three questions: 1) how did branching deregulation impact the mortgage 
market, 2) did branching deregulation impact house prices, and 3) is the end effect on house prices channeled via a response of the mortgage market. Detailed information on the volume and terms of individual mortgage loans is available from the Home Mortgage Disclosure Act (HMDA) database. County-level house price indexes, in turn, are compiled by Moody's Economy.com. We merge both data sources with the Rice-Strahan index of branching deregulation.

We observe mortgage loans at the county level, which affords a large cross section. HMDA reports the number, volume, denial rates, securitization and loan-to-income ratios of mortgages originated both by commercial banks and Independent Mortgage Companies (IMCs). By definition, IMCs are non-depository lending institutions that are not affected by bank branching deregulations. They provide a natural placebo sample, which should not respond to the treatment. The possibility of a differential response across lending institutions sharpens the causal interpretation of our results. If deregulation were motivated by an expected increase in the demand for mortgages, it would also correlate significantly with the volume and conditions of loans originated by IMCs. If a differential response exists between commercial banks, our treated population, and IMCs, our placebo sample, the expansion of credit induced by deregulation cannot be the outcome of demand conditions.

We also observe county-level house price indices. We ask whether their dispersion across states is significantly related to the chronology of branching deregulation, i.e. whether an exogenous change in the availability of credit has end effects on the price of housing. The price of real estate can of course differ geographically because of the supply of housing. Saiz (2010) has compiled information on local topographic characteristics to capture the amount of developable land in a given area. His measure builds from pre-existing geographic conditions, and is therefore exogenous to the contemporaneous economic context. We ask whether the (exogenous) shift in credit supply has a differential effect on the demand for houses - and ultimately house prices - depending on whether a county is situated in an area where house construction is particularly inelastic. Such differential response once again sharpens the causal interpretation of our results.

In the U.S., urban counties are grouped into Metropolitan Areas (MSA) that sometimes straddle state borders. These counties provide a focused sub-sample where a regression discontinuity approach is possible. In such a sub-sample, treated and control counties are neighbors, belong to the same MSA, and presumably share other unobserved characteristics. The approach helps put to rest concerns that omitted variable biases plague our estimations. For instance, local amenities, industrial structure, or growth performance can simultaneously 
impact the mortgage markets, house prices, and perhaps the dynamics of deregulation as well. We begin to address these concerns with county-level fixed effects, and the placebo sample that helps ascertain the exogeneity of branching deregulation. A regression discontinuity approach takes care of omitted variables in an exhaustive manner, as any local, unobserved county characteristic is held constant in a sample of border counties. We implement the approach for both mortgage and house prices regressions.

We find the number and volume of mortgage loans rise with the deregulation episodes, while denial rates fall. These responses are significant for banks classified as prime lenders, and larger but not always significant for sub-prime lenders. In addition, the effects we identify are not channeled via an increase in the fraction of loans that are securitized. Interestingly, no systematic change is discernible for mortgage loans originated by IMCs. Such a differential effect suggests that the shift in credit we observe cannot be due to demand. If it were, IMCs would also react, as we would observe a universal response of credit. All our conclusions are sharpened in a sub-sample formed by counties neighboring a state border. Such confirmation suggests deregulation, credit, and house prices are not all driven by unobservable variables. If they were, the relation we document would be weakened in neighboring counties that belong to the same metropolitan area.

House prices increase significantly in response to deregulation. The effect prevails holding constant a battery of conventional controls for changes in the price of housing, including population and income growth rates. We also allow for an autoregressive component accounting for potential momentum. Interestingly, the response of house prices is non-linear, as it depends on the constructability at the MSA level. The unconditional response of house prices to deregulation is not always significant, but it becomes strongly positive and significant with a control for the elasticity of housing supply. In MSAs where constructability is elastic, the effect of branching deregulations is muted. Once again, the results are sharpened in a sub-sample formed by border counties.

Finally, the end effect of branching deregulations on house prices works via the increase in the supply of mortgage credit. We regress house prices on the number, volume and denial rates of mortgage loans, instrumented by the deregulation episodes. The index passes the conventional tests for weak instruments with flying colors. Branching deregulations are quantitatively important in accounting for the expansion of credit supply between 1994 and 2005: The geographic distribution of the credit boom since 1994 is well explained by branching regulations, in an instrumental variable sense. In addition, a shift in credit supply has causal consequences on house prices. Our estimates of this causal effect suggest branching deregulation may explain up to 5 percentage points of the annual growth rate in house prices. 
The boom in U.S. house prices reversed from 2006. We investigate whether the geographic dispersion in this reversal can be attributed to deregulation. We find a systematic, significant effect: the growth rate in house prices tend to become most negative in deregulated states. This is a causal consequence of deregulation, comparable in magnitude to the positive coefficient we document pre-2006. The fall in house prices post-2006 is most pronounced in counties where housing construction is inelastic, and house prices increases most on the way up, prior to the 2006-2008 reversal.

Mian and Sufi (2009) and Glaeser, Gottlieb and Gyourko (2010) also use HMDA data to study mortgage credit and housing prices. Mian and Sufi show the growth in mortgage credit is associated with house price growth rates during the period 2002-2005. They refrain, however, from any causal interpretation, as they "do not have direct instruments for an expansion in the supply of credit" (page 1493). Glaeser, Gottlieb and Gyourko do not find evidence that mortgage credit correlates with changes in house prices over the 19962006 period. But they, too, refrain from drawing causal conclusions as they do not identify exogenous shifts in mortgage credit.

Our paper confirms the findings in Mian and Sufi (2009) that improved credit availability facilitates access to home ownership, with end effects on house prices. Mian and Sufi (2009) stress the role of securitization. The effects we uncover work via an expansion of the non-securitized mortgage market. Our channel is therefore distinct from theirs, but not mutually exclusive. The differential response of IMCs vs. commercial banks to the deregulation episodes guarantees that causality goes from an exogenous shift in (non securitized) credit supply to house prices. Changes in securitization, on the other hand, can depend on (expected) developments on the real estate market, which can obscure causal inferences.

Our results that the volume and number of mortgage loans increase with branch deregulation seem to contradict the findings of Rice and Strahan (2010). They focus on bank loans contracted by small firms. They find price effects but no overall quantity response: interest rates fall, bank debt rises but not total borrowing by firms. Rice and Strahan conclude the lack of a response in overall firm borrowing underlines the possibly ambiguous impact of competition in the banking sector, because of adverse selection or the destruction of privileged relationships. Banks choose to ration credit to firms, even though borrowing costs have decreased.

We find positive end effects in the mortgage market. The number of loans increases and denial rates fall, which suggests a response at the extensive margin. But we observe mortgage lending on the part of banks, not debtors' overall portfolios. It is entirely possible overall 
household debt remains unchanged, as borrowers reallocate their debt towards mortgage loans. That would mimic exactly what Rice and Strahan find for firms that resort increasingly to bank credit in response to the deregulation. Since no mortgage price data is available from HMDA, it is not possible to explore whether interest rates on mortgages respond to deregulation in the same way that Rice and Strahan document loans to firms have.

That deregulation should account for a sizeable proportion of the change in the mortgage market since 1994 in an instrumental variable sense is useful. It suggests bank branching regulations impose quantitatively important constraints on the availability of mortgage loans, with end effects on the prices of houses. Branching restrictions, and the ensuing market structure in mortgage loans, contribute to explaining in a causal sense the geographic dispersion in house price dynamics across the U.S. This is true both on the way up until 2005, and on the way down more recently.

The rest of the paper is structured as follows. Section 2 introduces our data. In Section 3 we discuss the effect of branching restrictions on the mortgage market, and in Section 4 we describe the effect on house prices. We also examine both mechanisms jointly in the context of an instrumental variable estimation. Section 5 concludes.

\section{Data}

The U.S banking sector has gone through decades of regulatory changes regarding banks' geographic expansion (Kroszner and Strahan, 1999, 2007). The deregulation wave culminated with the passage of the 1994 Interstate Banking and Branching Efficiency Act (IBBEA). Banks, national or state chartered, could then formally open branches across state borders without any formal authorization from state authorities. Even though the IBBEA authorized free interstate branching, it also granted individual states considerable power in deciding the rule governing entry by out-of-state branches.

States could restrict (i) the minimum age of the branching bank, (ii) de novo branching, (iii) the acquisition of individual branches, and (iv) the total amount of statewide deposits. According to restriction (i), states could impose a minimum age for the acquiring bank. Restriction (ii) stipulated that the opening of new branches required explicit agreement by state authorities. Restriction (iii) imposed that an interstate merger involving several branches rather than the whole target bank must be agreed explicitly by the state. Finally, the deposit cap allowed states to limit the total amount in insured depository institutions controlled by a single bank or bank holding company. 
As discussed in Johnson and Rice (2008), several states exercised their authority under the new law and opposed out-of-state branching by erecting barriers. This practice de facto hampered banking competition across states. Rice and Strahan (2010) describe these barriers and introduce a time varying index recording each of the four possible restrictions on interstate branching. Their index runs from 1994 to 2005 and takes values between 0 and 4. We reverse their index so that higher values are for states more open to out-of-state entry.

The Home Mortgage Disclosure Act was passed in 1975 with a view to forcing discrimination cases out onto the public stage, and to fostering the dissemination of information about housing investment. Under the Act, any commercial bank must report HMDA data if it has received a loan application, and if its assets are above an annually adjusted threshold. Non-depositary institutions, such as Independent Mortgage Companies, must also report if their house purchase loans portfolio exceeds 10 millions USD. Reporting commercial banks can be affiliates of bank holding companies or subsidiaries of depository institutions. They are regulated by the Office of the Comptroller of the Currency, the Federal Reserve Board, or the Federal Deposit Insurance Company. Independent mortgage companies, instead, are non-depository for-profit lenders. They are supervised at the federal level by the Department of Housing and Urban Development. HMDA data cover information on the borrowing individual (race, ethnicity, income), the loan's characteristics (response, reason for denial, amount - but not the interest rate), and the lending institution.

Given the importance of the placebo sample formed by IMCs, we describe in Table 1 the main characteristics of mortgages originated by both commercial banks and IMCs. Panel A of the Table reports the main characteristics of the loans originated by both types of financial intermediaries for the purchase of owner occupied houses. Over the whole time period we consider, IMCs tend to receive fewer loan applications, and originate fewer loans. IMC loans are on average slightly smaller, at 78,000 USD compared to 90,000 USD for commercial banks. Interestingly, denial rates are higher on average for IMCs, around 30 percent, than for commercial banks, where they are only around 16 percent. The rates at which both markets have expanded since 1993 are virtually identical. For instance, in 2005 average denial rates are still 16 percent in commercial banks and 25 percent in IMCs. Between 1995 and 2005, loan values have increased by 90 percent for commercial banks, and by 100 percent for IMCs. Panel B illustrates the fact that IMCs were more active in loans insured by the Federal Housing Administration (FHA) at the beginning of the sample. But that trend actually reversed in the late 1990s. By 2005, commercial banks lent the majority of FHA insured loans, with face values that are virtually identical across both type of lenders. Table 1 suggests there are no systematic large differences in the markets catered by IMCs or 
by commercial banks that could explain a putative systematic difference in their respective responses to state-level deregulations.

We aggregate the HMDA dataset up to the county level. We keep track of the number and total dollar amount of loans originated in each county for purchase of single family owner occupied houses. Loan volume is the total dollar amount aggregated at the county level. We compute the denial ratio as the number of loan applications denied divided by the number of applications received. We also obtain the fraction of loans originated that are securitized. Securitized loans are defined as those sold within a year after origination to another nonaffiliated financial institution or government-sponsored housing enterprise. Finally, the loan to income ratio is computed as the principal dollar amount of originated loan divided by total gross annual applicant income. The five variables are computed between 1993 and 2005.

County level house price indexes are collected by Moody's Economy.com, and refer to the median house price of existing single family properties. The series compounds data from a variety of sources including the US Census Bureau, regional and national associations of Realtors, and the house price index computed by the Federal Housing Finance Agency (FHFA). The sample covers metropolitan counties where Moody's Economy.com index tracks annual changes in house prices. Figure 1 illustrates the data's geographic coverage. A prominent alternative would be to use the Case-Shiller-Weiss index, that measures changes in housing market prices holding quality constant. Unfortunately, coverage includes 358 counties only, as compared with 1,055 for the data we use in the main text. But we have verified our conclusions continue to hold when we implement our estimations using the Case-Shiller-Weiss index, in spite of the heavily reduced sample of counties. These results are reported in our Appendix.

Controls for local economic conditions are obtained from the Bureau of Economic Analysis. We collect nominal income per capita and population growth rates at the county level. Income per capita is converted in real dollars using the national Consumer Price Index from the Bureau of Labor Statistics. With HMDA data, we identify the location of lenders, and compute a Herfindahl index of the concentration in loan origination at county level, a measure of local market power. Finally, we take the index of house constructability from Saiz (2010). Saiz processed satellite-generated data on water bodies, land elevation, and slope steepness at the MSA level to compile an index of land constructability for all main metropolitan areas in the U.S. The sample is slightly reduced relative to the rest of our data, but it still covers all metropolitan areas with more than 500,000 inhabitants with available satellite data. 
Table 2 lists the variables contained in our dataset, along with their definitions and data sources. Table 3 reports some summary statistics. We separate out loans characteristics originated by commercial banks, independent mortgage companies, and banks classified as prime or subprime by the Department of Housing and Urban Development. We have data for 1, 055 counties. For conventional banks the average annual growth rate in the number of loans is $13 \%$, and the annual average growth rate in loan value is $18 \%$. The fraction of these loans that are securitized grows at $4 \%$ per year. Denial rates fall on average by $3 \%$, while loan to income ratios rise by $2.4 \%$. During the same period, our measure of market concentration for mortgage loans falls on average by $5 \%$. For each measure, volatility comes mostly from time variation, rather than dispersion across counties.

On the whole, the mortgage market developed less on average for mortgage companies, with loans numbers and volume expanding less, and denial rates remaining virtually unchanged. In contrast, the subprime mortgage market expanded faster on average than prime banks, across all four measures we observe. Subprime lenders are not active in all counties, although they are in most. Such average trends are indicative of differential dynamics across market categories. But of course they are silent about geographic dispersion since they are merely first moments.

House prices increased at an average annual rate of $2.96 \%$ between 1994 and 2005, more than twice as fast as average county per capita income. In fact, per capita income and population grew at virtually identical average rates, around $1.35 \%$. The observed volatility in house prices comes mostly from time variation, just as loans characteristics did. The same is true of per capita income growth. The Rice and Strahan index of branching deregulation is observed at the state level. On average, the index equals 1.26, indicating that the average state is relatively restricted, with just below three out of four possible restrictions effectively implemented. Dispersion in the index comes from both state and time variation, which will help identification. Finally, the Saiz index of housing supply elasticity is available for 270 MSAs only, or 907 counties.

\section{Branching Regulation and Mortgage Credit}

Regulations on the geographic expansion of U.S. banks have long been used to characterize the economic role of financial intermediation. Thanks to a history of sequential relaxation in both banking and branching regulations, U.S states provide a useful laboratory to study the consequences of changes in the market structure of the banking sector. Jayaratne and 
Strahan (1996, 1998), and Stiroh and Strahan (2002) have, for instance, argued that earlier episodes of intrastate branching reforms have triggered observable changes in the degree of competition amongst banks. With deregulation, banks have improved efficiency and lowered non-interest costs. The quality of lending has increased, with lower loan prices, lower loan losses, and revamping of overall bank performance.

We take inspiration from the empirical approach in this literature. We trace the consequences on the mortgage market of interstate branching deregulation in the banking sector. We depart from most of the literature, and focus on a specific type of bank lending, mostly aimed at households proposing to acquire real estate property. Identification is conventional and akin to a treatment effect, where deregulated states are treated. We estimate

$$
\Delta L_{c, t}=\beta_{1} D_{s, t}+\beta_{2} \Delta X_{c, t}+\alpha_{c}+\gamma_{t}+\varepsilon_{c, t},
$$

where $c$ denotes county-level and $s$ denotes state-level data. $\Delta L_{c, t}$ is one of the five measures of activity on the mortgage market we observe: growth in the number and volume of mortgages by county, changes in the denial rate, the loan to income ratio, and loan securitization. $\Delta X_{c, t}$ summarizes county-specific controls, which in practice include current and past growth rates in income per capita, population and house prices, and changes in the Herfindahl index of concentration in the mortgage market. Identification rests on the dispersion across states (and time) of deregulation, captured by $D_{s, t}$. The variable $D_{s, t}$ aggregates the four elements of restrictions to interstate branching compiled by Rice and Strahan. It takes values between 0 , for states with the highest numbers of restrictions, and 4, for the most deregulated states.

The controls in $\Delta X_{c, t}$ help ascertain the effect we identify works through changes in the supply of mortgage credit. They hold constant conventional determinants of credit demand at the county level. A Herfindahl index holds constant potential county-level heterogeneity in competition on the mortgage market. We focus on the consequences of deregulation on the growth of the mortgage market, which sets non-stationarity concerns to rest. We allow for country-specific trends in the level of credit via the inclusion of $\alpha_{c}$. Our data regroups vastly heterogeneous counties, visually identified in Figure 1. Such heterogeneity presumably carries through into the underlying dynamics of the size and characteristics of local mortgage markets. We seek to identify breaks in these county-specific trends that occur with deregulation. So we estimate growth effects of deregulation. In addition, $\gamma_{t}$ accounts for the overall U.S. credit cycle. Since deregulation is state-specific but loans are observed for each county, standard errors are clustered at the state level (see Moulton, 1990 and Bertrand, Duflo and Mullainathan, 2004). 
Table 4 presents the results. Panel A focuses on loans originated by commercial banks. The first three columns reveal the number of loans and their overall county value both increase significantly with deregulation, while denial rates fall. All three estimates suggest the actual size of the mortgage market expands through a relaxation of the (non-interest) terms of the loans originated. The point estimate for $\beta_{1}$ in the first column implies that states where branching is de facto unfettered experience an annual growth rate in originated loans 12 percent higher than states imposing full restrictions. The loan to income ratio, however, does not increase with deregulation.

The last specification in Table 4 suggests $\beta_{1}$ is not different from zero for the proportion of originated loans that are resold within the year to other non-affiliated financial institutions or government-housing sponsored enterprises. In other words, the increase in the overall size of the mortgage market works via non-securitized loans. Banks originate more mortgages, but apparently not with the purpose of contracting credit risk that they propose to immediately diversify away onto other intermediaries.

A shift in the supply of mortgage loans is entirely compatible with unchanged overall household debt level. Just as Rice and Strahan found that firms increased bank debt in response to deregulation, but not their overall borrowing, it is possible more households contract a mortgage while keeping their overall indebtedness constant. HMDA only reports loans originated but no information is available about the stock of debt on the demand side. A definite confirmation of Rice and Strahan's conclusions on the mortgage market is therefore not possible.

Panel B in Table 4 reports estimates of equation (1) for loans originated by Independent Mortgage Companies (IMCs). These institutions are unaffected by changes in branching regulations, which affect depository institutions only. We find deregulation has no effect on the lending practices of IMCs. In particular, the point estimates of $\beta_{1}$ are observably closer to zero for IMCs than for other lenders, up to an order of magnitude smaller. There is a differential effect of branching regulations across categories of lenders. This sharpens the causal interpretation of our estimates. If deregulation were endogenous and simply responding to expected large increases in the demand for mortgage, $\beta_{1}$ should be significant across both panels in Table 4 .

The absence of any significant consequence of deregulation in a placebo sample puts to rest the possibility that $\beta_{1}$ is significant because overall economic activity has improved with the deregulation. For instance, Jayaratne and Strahan (1996) show that following intrastate branching deregulation, increased efficiency in the banking sector has boosted state-level 
economic growth. Black and Strahan (2002) estimate that new business formation has increased following intrastate banking reform. Morgan, Rime and Strahan (2004) find that interstate banking deregulation has reduced the volatility of state-level business cycles, as cross-state banking helps insulate each state from shocks to its own banking system. But such systematic responses of the local economy to deregulation cannot explain a differential response across lenders. The deregulation only affected mortgage loans originated by treated banks, not the whole mortgage market.

In Table 4, equation (1) is estimated on the full sample of 1,055 counties with available data. Table 5 focuses instead on the sample formed by counties on each side of a state border. We select in our data (36) MSAs that straddle a state border, and estimate equation (1) on the thus chosen sample of (248) border counties. Figure 2 illustrates the geographic coverage of the reduced cross-section. Our purpose is to implement a regression analysis that identifies the effects of branching deregulation using the discontinuity in branching restrictions at state borders. The main assumption is that control variables in equation (1) - observed or unobserved — vary continuously around the border. Indeed, adjacent counties in MSAs have presumably a high degree of social and economic integration. Then, an estimation focused on the MSAs that straddle state borders holds constant all co-variates, including unobserved ones. The local sub-sample provides a rigorous treatment of a potential omitted variable bias.

A regression discontinuity framework is important because it alleviates concerns of reverse causality. Suppose significant estimates of $\beta_{1}$ obtained because demand conditions were looking up. Then $\beta_{1}$ would be positive because the demand for credit is booming and banks are lobbying for deregulation. But presumably demand conditions are relatively homogeneous within a metropolitan area, whether it straddles a border or not. A state-specific deregulation dummy variable should not be relevant to explaining differential characteristics of the mortgage market in such locally defined sub-samples.

A regression discontinuity framework is also important in relation to the recent findings in Huang (2008). Huang finds the growth effects documented by Jayaratne and Strahan (1996) in response to intrastate banking deregulation prevail mostly in the early 80's, and in later years only for a few contiguous states. It is therefore important to ascertain that our conclusions hold true universally, for some of the literature has concluded otherwise as regards the growth effects of intrastate banking deregulation.

Table 5 reports regression discontinuity estimates of equation (1) for commercial banks and IMCs. To account for spatial autocorrelation corresponding to potential border specific 
developments, standard errors are now clustered at the state and border levels. We use the multi-way clustering approach introduced in Cameron, Gelbach, and Miller (2006) and Petersen (2009). The approach allows for unrestricted residual correlation within states, and across counties that are in the same MSA but not in the same state. As before, we find the number and volume of mortgage loans originated by depository institutions increase significantly, and denial rates fall. There is no change in the fraction of loans that are securitized. All these responses continue to be absent for loans originated by IMCs. In other words, the differential effect documented in Table 4 survives a discontinuity regression approach. The mortgage market expands in counties that deregulate, while their immediate untreated neighbor sees no change in the size of the market. What is more, only treated banks respond.

Table 6 repeats the regression discontinuity estimation. But it is now performed on two samples of commercial banks chosen according to the riskiness of their portfolio. Each year, the Department of Housing and Urban Development examines the overall risk content of banks portfolios, and issues a classification between prime and subprime depository institutions. The classification is out of the banks' control, and is meant to reflect an objective assessment of the riskiness of their lending policy. The two panels in Table 6 reveal some differences. Panel A, focused on prime banks, implies estimates virtually identical to Table 5 , which suggests the significant response of mortgage markets to deregulation is the result of decisions on the part of prime banks. Panel B, focused on subprime banks, reports estimates of $\beta_{1}$ that are almost all insignificant. The point estimates, however, are higher than for prime banks. Denial rates, in particular, fall dramatically, which could be indicative of subprime banks aggressively lowering their lending standards with the deregulation. However, the comparison ought to be taken with a grain of salt, as estimates are imprecise in the sample of subprime banks. There are fewer observations, and most sub-prime activity is concentrated towards the end of our sample. Table 5 does suggest, however, a heterogeneous response to deregulation on the part of subprime banks.

\section{Credit Supply and the Price of Housing}

We now study whether the lifting of branching restrictions has affected house prices. We verify whether house prices respond to deregulation because of the changes in mortgage loans. Following deregulation, an expansion of credit can affect house prices in two ways. First, it can boost the demand for housing as mortgage rates fall and/or more investors gain access to ownership. This would happen for instance in the presence of credit constraints, 
which the deregulation relaxes. Second, it can affect the risk profile of the asset, increasing the ease of resale, and thus its liquidity. In both cases the price of housing should rise following deregulation.

\subsection{Branching Restrictions and House Prices}

A burgeoning literature has taken interest in the end effects of innovation in the financial sector on house prices. Dell'Ariccia, Igan and Laeven (2008), Demyanyk and Van Hemert (2009), Mian and Sufi (2009) and Keys, Mukherjee, Seru and Vig (2010) find the securitization of mortgage loans has been associated with worsened lending standards, and an expansion in mortgage credit. In particular, Mian and Sufi show the expansion of mortgage credit due to securitization was particularly pronounced in U.S cities with high home price appreciation. These papers argue that the peak in mortgage lending to subprime borrowers has played an important role in explaining the recent house price booms. Securitization facilitates access to credit, and therefore to property as well. But that happens at the expense of the risk profile of the marginal borrower.

Our contribution relative to this literature is two-fold. First, securitization is likely to respond endogenously to (unobserved, expected) changes in equilibrium credit. The empirical link between house prices and securitization can therefore conflate the effects of shocks to both the supply and demand sides of the credit market. Branching deregulation, in contrast, affects only the supply size of the credit market, and does so only amongst treated banks. Second, the channel we identify is effectively distinct from - but not competing with - loan securitization. The increase in the supply of mortgage loans that we document occurs independently of a rise in the fraction of securitized loans.

It is well known house prices display considerable geographic heterogeneity in the U.S. Such heterogeneity can arise from differences in constructability, for instance because of local costs or land use regulation (see Gyourko and Saiz, 2006; Gyourko, Saiz and Summers, 2006). But it can also come from the demand side of the market, simply because income per capita and population are geographically heterogeneous (see Glaeser and Gyourko, 2007, 2008; Lamont and Stein, 1999). Here, we propose to explain the geographic heterogeneity of house

prices with differences in the availability of credit across states, which reflect heterogeneous banking regulations. We hold constant county-level conditions with adequate intercepts and time-varying controls. If state-specific regulations continue to be significant, that means the geographic dispersion of house prices in the U.S has a state component - which happens to correlate significantly with bank branching regulations. 
Our empirics closely follow the treatment approach described in the previous section. We estimate the consequences of state branching deregulations on the trend growth in house prices, making use of the fact the deregulation episodes are exogenous to contemporaneous economic circumstances. We estimate

$$
\Delta H_{c, t}=\beta_{1} D_{s, t}+\beta_{2} D_{s, t} \cdot \eta_{c}^{S}+\beta_{3} \Delta X_{c, t}+\alpha_{c}+\gamma_{t}+\varepsilon_{c, t}
$$

where $c$ denotes county-level and $s$ denotes state-level data. The variable $D_{s, t}$ continues to denote the Rice-Strahan deregulation index. $\Delta H_{c, t}$ is the annual growth rate in the county house price index put together by Moody's Economy.com, and $\Delta X_{c, t}$ summarizes additional determinants of house prices documented in the literature. For instance, Glaeser and Gyourko $(2007,2008)$ include rents as an independent variable, while Lamont and Stein (1999) include contemporaneous and lagged per capita income. We have no information on rents at the county level, so we approximate local influences on the real estate market with contemporaneous and lagged growth rates in per capita income and population. In addition, following Case and Shiller (1989), we allow for momentum in house prices with a lagged dependent variable. We experimented with more than one lag with no consequences on our results. Regressions are again performed on first-differenced variables to put non-stationarity concerns to rest. As before, we seek to identify breaks in the trend growth of house prices that are caused by deregulation, allowing for heterogeneous trends at the county level. ${ }^{1} \mathrm{We}$ include year effects, which holds constant country-wide cycles in house prices. The focus is squarely on the state-level dispersion in real estate prices. Standard errors are clustered at the state level.

The coefficient of interest is $\beta_{1}$, which traces the consequences on real estate prices of deregulation episodes. Even though $D_{s, t}$ triggers exogenous change in the supply of credit, the end effect on house prices can reflect county-specific developments on the supply of houses. Unconditionally positive estimates of $\beta_{1}$ can be significant because deregulating states happen to be those where house construction is severely restricted. Estimates of $\beta_{1}$ would then be significant, but not because expanding mortgage credit stimulates the demand for housing. We need to hold constant the supply of houses in equation (2). We do so thanks to the index of topographic constructability put together by Saiz (2010), which we denote by $\eta_{c}^{S}$. The variable is effectively observed at the MSA level, so we actually assume the

\footnotetext{
${ }^{1}$ The vast majority of papers using disaggregated house price indexes refrain from using the information contained in the level of indexes. For instance, Himmelberg, Mayer and Sinai (2005) recommend to focus exclusively on the growth rates in house prices as implied by FHFA indexes. Units are often not directly comparable and the cross-section can be affected by the statistical methodology used in computing indexes. We follow the standard and estimate equation (2) in growth rates.
} 
topography is the same across the counties that form the MSAs Saiz considers. We expect $\beta_{2}<0$, as house prices should respond less to a credit boom in counties with plentiful constructable land.

Table 7 presents our estimates of equation (2) for different control sets. Unconditional estimates of $\beta_{1}$ are insignificant, whether they are obtained from the total sample of counties with house price information (column 1), or if we constrain the sample to counties where $\eta_{c}^{S}$ is available (column 2). Interestingly, $\beta_{1}$ becomes positively significant when we control for the elasticity of house supply $\eta_{c}^{S}$. The interaction term, in turn, is significant and negative, with $\beta_{2}<0$ in all instances. These conclusions continue to prevail no matter the control set across the specifications in Table 7. It is only in counties with a topography that makes house construction difficult that deregulations affect house prices significantly. Their effect is muted elsewhere. ${ }^{2}$

Controls for population and income growth do not alter the impact of deregulation on house prices. It is difficult to think of shocks to the demand for credit that do not correlate with per capita income or population growth, but do correlate with $D_{s, t}$, especially given the evidence in the previous section that deregulation only affects treated banks in treated states.

The results in Huang (2008) help further assuage such a concern for an omitted variable bias. Using counties bordering a state frontier, Huang concludes there are relatively few instances where banking deregulations have had differential growth effects. This is especially true of the most recent period. In other words, the border discontinuity in per capita income growth rates is minimal in the recent time period. Income per capita growth rates are on the whole not affected by the border, and therefore not by the most recent deregulation chronology either. Observed or unobserved controls in equation (2) thus presumably vary continuously around state borders. A regression discontinuity estimation will help account for potential omitted controls. Table 8 presents the results. Interestingly, all coefficients become larger in magnitude, with unconditionally positive and significant estimates of $\beta_{1}$. When an interaction term involving $\eta_{c}^{S}$ is included, estimates for $\beta_{1}$ roughly double in magnitude, and continue to be significantly positive. Estimates of $\beta_{2}$, in turn, continue to be negative and significant.

\footnotetext{
${ }^{2}$ Equation (2) suffers from a conventional bias due to the presence of lagged dependent variables in a regression with fixed effects. As the implied bias is bounded above by the coefficient estimated with an OLS estimator (see Blundell and Bond, 2000), we re-estimated equation (2) with OLS but without intercepts $\alpha_{c}$. All our results were confirmed, with minimal changes in coefficient estimates. We conclude the bias is negligible in our dataset and specification.
} 
These results suggest the relaxation of branching regulations has a causal impact on house prices at the county level. The end effect depends on the elasticity of housing supply. We classify a county as "highly elastic" if it falls in the top $10 \%$ MSAs according to $\eta_{c}^{S}$, and "highly inelastic" if it falls in the bottom 10\%. On the basis of column 4 in Table 8 , house prices do not react in highly elastic counties. But in highly inelastic counties, the lifting of branching restrictions increases the growth rate of house prices by 5 percent per year. This is a large number, considering the mean growth in real house prices over the 1994-2005 period is $3 \% .^{3}$ A natural interpretation of such estimates is that bank branching deregulations affect the supply of mortgage credit, and either stimulates the demand for houses, or modify their risk profile or liquidity. The next section investigates rigorously the empirical validity of this channel.

\subsection{The Credit Channel}

In Section 3 we documented a significant effect of branching deregulations on the supply of mortgage loans. We showed the response exists only amongst treated banks located in treated states. This rules out explanations based on an endogenous demand for deregulation, which would arise from both independent mortgage companies and treated banks located in the same county. In Section 4, we documented the very same deregulation episodes result in rising house prices. We showed the price response prevails mostly in treated counties where the constructability of houses is physically limited, and continues to exist between neighboring counties on either side of a state border. In both Sections, we stressed a causal mechanism going from deregulation to the supply of mortgage credit, and from deregulation to the demand for housing.

We now investigate whether the expansion in credit triggered by deregulation is a quantitatively relevant reason for the response of house prices. We do so by combining the intuitions from equations (1) and (2). In particular, we perform an instrumental variable (IV) estimation of

$$
\Delta H_{c, t}=\delta_{1} \Delta L_{c, t}+\delta_{2} \Delta X_{c, t}+\alpha_{c}+\gamma_{t}+\varepsilon_{c, t}
$$

where $\Delta L_{c, t}$ is instrumented by the deregulation episodes, i.e.

$$
\Delta L_{c, t}=\beta_{1} D_{s, t}+\beta_{2} \Delta X_{c, t}+\alpha_{c}+\gamma_{t}+\varepsilon_{c, t},
$$

\footnotetext{
${ }^{3}$ We have verified our results are identical in the alternative dataset of counties based on the Case-ShillerWeiss indices. The coverage is substantially smaller with only 356 counties, out of which 81 are straddling a state border. In Appendix Tables A1 and A2 we show the end estimates of $\beta_{1}$ and $\beta_{2}$ are virtually identical.
} 
The notation is unchanged. Equation (3) continues to include conventional controls for house price dynamics. We perform the IV estimation on the reduced sample of border counties. The system formed by equations (3) and (4) investigates econometrically the relevance of branching deregulations to account for the cross-section in $\Delta L_{c, t}$, and ultimately in house prices, $\Delta H_{c, t}$.

Table 9 presents regression results for three measures of $\Delta L_{c, t}$ : the number and volume of loans, and the denial rate. The F-test for weak instruments evaluates the null hypothesis that the instruments $D_{s, t}$ are excludable from the first stage regression (4). Staiger and Watson (1997) and Stock, Wright and Yogo (2002) recommend the F-statistics should take values above 10, lest the end estimates become unreliable. Branching deregulations satisfy the recommendation in all three specifications in Table 9. The explanatory power of branching deregulations is satisfactory in an instrumental sense: the dispersion in countylevel conditions of the mortgage market is well explained by $D_{s, t}$.

Estimates of $\delta_{1}$ are always significant in Table 9. Growing volume and number of loans, once instrumented by $D_{s, t}$, result in rising house prices. And low denial rates, instrumented by $D_{s, t}$, also affect house prices in a causal sense. Thus, the deregulation-induced fraction of $\Delta L_{c, t}$ affects the price of houses significantly. Interestingly, a sample focused on subprime banks implies fundamentally different conclusions. In unreported results, we estimated the system of equations (3)-(4) on sub-prime banks only. The instrument set never passed the Staiger-Watson test, with F-test close to zero, and $\delta_{1}$ insignificant.

\subsection{Branching Deregulation and the 2006-08 House Prices Bust}

After a decade of steady increase the aggregate price of U.S. housing has reversed trend, beginning in 2006. According to some recent studies (Demyanyk and Van Hemert (2000) and Sufi and Mian (2009)) the run-up and subsequent reversal in house price was caused by excessive mortgage originations. In the previous sections we found that the 1994-2005 deregulation of bank branching has caused an outward shift in the supply of mortgage credit and engendered an increase in the growth rate of house prices. In this section we ask whether the size of the house price drop post-2005 is more severe in states that had fewer regulatory constraints in 2005. We measure the state of the game in 2005, since this is the last year for which the Rice-Strahan index is observed.

We first estimate a pure cross-section:

$$
\Delta H_{c}=\beta_{1} D_{s, 2005}+\beta_{2} D_{s, 2005} \cdot \eta_{c}^{S}+\beta_{3} \Delta X_{c}+\varepsilon_{c}
$$


where the growth in house prices $\Delta H_{c}$ is measured between 2005-06, 2006-07 and 2007-08. The results are reported in the first three columns of Table 10. Since it is a pure cross-section, we are unable to include in equation (5) the same controls included in its panel counterpart, i.e., equation (2). To bring the specification post-2005 closest to its counterpart in the earlier period, we construct a pseudo-panel:

$$
\Delta H_{c, t}=\beta_{1} D_{s, 2005}+\beta_{2} D_{s, 2005} \cdot \eta_{c}^{S}+\beta_{3} \Delta X_{c, t}+\gamma_{t}+\varepsilon_{c, t},
$$

where the time dimension is obtained by repeating observations on house price growth rates for the four years with available data, until 2008. Equation (6) now includes the control set introduced in Section 4, i.e. a momentum term and the time-varying co-variates summarized in $\Delta X_{c, t}$.

Table 10 presents the results for the sample of counties straddling a state border. In cross-section, estimates of equation (5) suggest deregulation continues to have a significantly positive impact on house prices until 2007. It is not until 2007-2008 that the earlier deregulation steps (measured in 2005) do explain the magnitude of the fall in house prices. In addition, the impact of deregulation is muted in counties where housing supply is responsive, i.e., ones where the increase in house prices was mitigated in the first place. The main result survives the inclusion of all controls, as illustrated in the last specification of Table 10. Estimates of $\beta_{1}$ continue to be significantly negative and of the same order of magnitude as our estimates for the boom period, reported in Table 8. We conclude house prices are affected by banking regulations, via their effects on the mortgage markets. That impact is causal. It mattered for both the real estate boom up until 2005, and for the subsequent crash, with coefficient estimates of similar magnitude.

\section{Conclusion}

The price of housing is influenced by access to credit, and ultimately by the regulation of financial intermediaries. We establish this claim in a causal sense thanks to the index of bank branching deregulation compiled by Rice and Strahan (2010). We show deregulation increases the number, volume and acceptance rates of mortgage origination. More loans are contracted, but not subsequently securitized. Nor indeed are sub-prime banks clearly more active. Importantly, only treated banks in treated counties respond to deregulation, which rules out explanations for our results based on unobserved shifts in the demand for credit. What is more, such differential effects are sharpened in a sample of metro areas that 
include counties bordering two or more states, where a regression discontinuity estimation is possible.

House prices rise in deregulated counties, and this response is particularly pronounced in counties where the supply of housing is inelastic. We estimate an acceleration in house prices of up to 5 percentage points increase in annual growth. This holds true across all U.S counties with house price data, but also for counties neighboring state borders. There, unobserved determinants for house prices presumably change continuously across the border, and the focus is squarely on the consequences of bank deregulation on house prices. The channel that goes from deregulation to house prices works via the response of mortgage credit supply.

During the 1994-2005 period, house prices increased because of the lifting of branching restrictions, and the implied mortgage boom. After 2006, however, the fall in house prices was sharpest in those deregulated states where bank branching restrictions were least implemented as of 2005. In as much as deregulation dates are orthogonal to economic fundamentals, such symmetry suggests over-reaction may have been at play, either during the run up, or the subsequent fall in house prices.

Identifying the sources of such over-reaction is beyond the remit of this paper. We offer nonetheless three conjectures. After deregulation, banks may have opened new branches, and collected more deposits. With more loanable funds, the supply of credit expanded and more borrowers became eligible for credit. Alternatively, deregulation triggered more bank competition. Loan costs fell and the terms of credit improved. As a result of such pro-efficient effects, more borrowers got access to credit. Third, deregulation meant banks could diversify risk, geographically or through securitization. Credit supply increased as a result. While we document an increase in the supply of credit that is not channeled by securitization, we cannot rule out the possibility of improved geographic diversification. ${ }^{4}$ In all three cases, credit supply expand. But each mechanism has potentially different consequences on house prices. Short of detailed data on banks' balance sheet, the price and non-price terms of loans, and the quality and composition of mortgage borrowers, we are unable to ascribe the over-reaction in house prices we document to a specific mechanism. In this paper we have focused on establishing a causal relation. We leave further explanations for subsequent work.

\footnotetext{
${ }^{4}$ Loutskina and Strahan (forthcoming) provide some evidence in this direction. They show that geographic diversification led to reduced lending standards, and ultimately the 2007-2008 crisis.
} 


\section{Appendix: Housing price regressions using the Case-Shiller-Weiss index}

Tab A1. Interstate branching deregulation and CSW house price index

County level linear regressions of the log change in the CSW House Prices on the Index of Branching Deregulation. Control variables include the lagged log change in House Prices, the Elasticity of Housing Supply, the current and lagged log change in county Income per capita, and the current and lagged log change in county Population. All variables are defined in Table 1. In column (1) the sample includes all US counties in urban areas for which mortgage data is available for the period 1993-2005. In columns (2)(4) the sample is limited to counties in MSAs for which Saiz (2010)'s measure of housing supply elasticity is available. The index of interstate branching deregulation ranges from 0 (most restricted) to 4 (least restricted). All regressions include county and year fixed effects. Standard errors are clustered by state. Estimates followed by ***,**, and * are statistically different from zero with $0.01,0.05$ and 0.10 significance levels, respectively.

\begin{tabular}{|c|c|c|c|c|}
\hline \multirow[b]{3}{*}{ Index of interstate branching deregulation } & \multicolumn{4}{|c|}{$\begin{array}{c}\text { Dependent Variables } \\
\text { House Prices }\end{array}$} \\
\hline & $(1)$ & $(2)$ & $(3)$ & $(4)$ \\
\hline & $\begin{array}{l}-0.005 \\
(0.006)\end{array}$ & $\begin{array}{l}-0.006 \\
(0.006)\end{array}$ & $\begin{array}{c}0.018^{* * *} \\
(0.006)\end{array}$ & $\begin{array}{c}0.008^{* * *} \\
(0.003)\end{array}$ \\
\hline $\begin{array}{l}\text { Index of interstate branching deregulation } \times \\
\text { house supply elasticity }\end{array}$ & & & $\begin{array}{c}-0.010^{* * * *} \\
(0.002)\end{array}$ & $\begin{array}{c}-0.005^{* * *} \\
(0.001)\end{array}$ \\
\hline Lagged house price & & & & $\begin{array}{c}0.438^{* * *} \\
(0.030)\end{array}$ \\
\hline Income per capita & & & & $\begin{array}{c}0.394^{* * *} \\
(0.085)\end{array}$ \\
\hline Lagged income per capita & & & & $\begin{array}{c}0.255^{* * *} \\
(0.055)\end{array}$ \\
\hline Population & & & & $\begin{array}{c}0.911^{* * *} \\
(0.186)\end{array}$ \\
\hline Lagged Population & & & & $\begin{array}{l}0.608^{*} \\
(0.208)\end{array}$ \\
\hline Observations & 4,269 & 3,537 & 3,537 & 3,243 \\
\hline N. of counties & 356 & 295 & 295 & 295 \\
\hline N. of states & 46 & 42 & 42 & 42 \\
\hline R2 within & 0.270 & 0.273 & 0.331 & 0.626 \\
\hline
\end{tabular}


Tab A2. Interstate branching deregulation and CSW house price index in counties within MSAs that straddle two or more US states

County level linear regressions of the log change in the CSW House Prices on the Index of Branching Deregulation. Control variables include the lagged log change in House Prices, the Elasticity of Housing Supply, the current and lagged log change in county Income per capita, and the current and lagged log change in county Population. All variables are defined in Table 1. In column (1) the sample includes all US counties in MSAs straddling two or more US states, and for which mortgage data is available for the period 1993-2005. In columns (2)-(4) the sample is limited to counties in MSAs straddling two or more US states and for which Saiz (2010)'s measure of housing supply elasticity is available. The index of interstate branching deregulation ranges from 0 (most restricted) to 4 (least restricted). All regressions include county and year fixed effects. Standard errors are clustered at the state level and the border level. Estimates followed by ***, **, and * are statistically different from zero with $0.01,0.05$ and 0.10 significance levels, respectively.

\begin{tabular}{|c|c|c|c|c|}
\hline \multirow[b]{3}{*}{ Index of interstate branching deregulation } & \multicolumn{4}{|c|}{$\begin{array}{l}\text { Dependent Variables } \\
\text { House Prices }\end{array}$} \\
\hline & (1) & $(2)$ & $(3)$ & $(4)$ \\
\hline & $\begin{array}{c}0.001 \\
(0.005)\end{array}$ & $\begin{array}{c}0.001 \\
(0.005)\end{array}$ & $\begin{array}{c}0.020^{* * *} * \\
(0.006)\end{array}$ & $\begin{array}{c}0.011^{* * *} \\
(0.005)\end{array}$ \\
\hline $\begin{array}{l}\text { Index of interstate branching deregulation } \times \\
\text { house supply elasticity }\end{array}$ & & & $\begin{array}{c}-0.011^{* *} \\
(0.002)\end{array}$ & $\begin{array}{c}-0.008^{* * *} \\
(0.002)\end{array}$ \\
\hline Lagged house price & & & & $\begin{array}{c}0.400^{* * *} \\
(0.056)\end{array}$ \\
\hline Income per capita & & & & $\begin{array}{c}0.238^{* *} \\
(0.076)\end{array}$ \\
\hline Lagged income per capita & & & & $\begin{array}{c}0.278^{* * *} \\
(0.062)\end{array}$ \\
\hline Population & & & & $\begin{array}{c}1.133^{* * *} \\
(0.398)\end{array}$ \\
\hline Lagged Population & & & & $\begin{array}{c}0.940^{* *} \\
(0.416)\end{array}$ \\
\hline Observations & 972 & 960 & 960 & 880 \\
\hline N. of counties & 81 & 80 & 80 & 80 \\
\hline N. of borders & 16 & 15 & 15 & 15 \\
\hline N. of states & 20 & 20 & 20 & 20 \\
\hline R2 within & 0.546 & 0.550 & 0.594 & 0.768 \\
\hline
\end{tabular}




\section{References}

Bertrand, M., E. Duflo and S., Mullainathan (2004), "How Much Should we Trust Differencein-Difference Estimators?" Quarterly Journal of Economics 119, 249-75.

Black, S. and P. E. Strahan (2002), "Entrepreneurship and Bank Credit Availability," Journal of Finance 57, 2807-2833.

Blundell, R. and S. Bond (2000), "GMM Estimation with Persistent Panel Data: An Application to Production Functions," Econometric Reviews 19, 321-340.

Cameron, C., J., Gelbach and D., Miller (2006), "Robust Inference with Multi-Way Clustering," NBER Technical Working Paper 327.

Case, K. E., and R. J. Shiller (1989), "The Efficiency of the Market for Single Family Homes," American Economic Review, 79, 125-137.

Dell'Ariccia, G., D. Igan, L. Laeven (2008), "Credit Booms and Lending Standards: Evidence from the Subprime Mortgage Market," IMF Working Paper

Demyanyk and Van Hemert (2009), "Understanding the Subprime Mortgage Crisis," Review of Financial Studies

Glaeser, E. and J. Gyourko (2006), "Housing Cycles," NBER W.P 12787

Glaeser, E. and J. Gyourko (2007), “Arbitrage in Housing Markets,” NBER W.P. 13704

Glaeser, E., J. D. Gottlieb and J. Gyourko (2010), "Can Cheap Credit Explain the Housing Boom?" mimeo Harvard University

Gyourko, J. and A. Saiz (2006), "Construction Costs and the Supply of Housing Structure," Journal of Regional Science, 46, 661-680.

Gyourko, J., A. Saiz and A.A. Summers (2008), "A New Measure of the Local Regulatory Environment for Housing Markets: The Wharton Residential Land Use Regulatory Index," Urban Studies, 45, 693-729.

Himmelberg, C., C. Mayer, and T. Sinai (2005), "Assessing High House Prices: Bubbles, Fundamentals, and Misperceptions," Journal of Economic Perspectives, 19, 67-92.

Huang R. (2008), "Evaluating the Real Effect of Bank Branching Deregulation: Comparing Contiguous Counties Across US State Borders," Journal of Financial Economics, 87, 678705 
Jayaratne, J. and P. E. Strahan (1996), "The Finance-Growth Nexus," Quarterly Journal of Economics, 111, 639-670.

Jayaratne, J. and P. E. Strahan (1998), "Entry Restrictions, Industry Evolution, and Dynamic Efficiency: Evidence from Commercial Banking," Journal of Law and Economics, 41, 239-273.

Johnson C, and T. Rice (2008), "Assessing a Decade of Interstate Bank Branching," Washington and Lee Law Review, 65, 73-127.

Keys, B., T. Mukherjee, A. Seru, and V. Vig (2010), "Did Securitization Lead to Lax Screening: Evidence from Subprime Loans," Quarterly Journal of Economics, 125, 307-362 Kroszner, R.S. and P.E. Strahan (1999), "What Drives Deregulation? Economics and Politics of the Relaxation of Bank Branching Restrictions," Quarterly Journal of Economics, 114, $1437-67$.

Kroszner, R.S. and P.E. Strahan (2007), "Regulation and Deregulation of the U.S Banking Industry: Causes, Consequences and Implications for the Future," Ch. 7 in Nancy Rose, ed., Studies in Regulation, Chicago: NBER and University of Chicago

Lamont, O. and J. Stein (1999), "Leverage and House-Price Dynamics in U.S. Cities," Rand Journal of Economics, 30, 498-514.

Loutskina, E. and P. Strahan, (forthcoming) "Informed and Uninformed Investment in Housing: the Downside of Diversification," Review of Financial Studies.

Mian, A. R. and A. Sufi (2009), "The Consequences of Mortgage Credit Expansion: Evidence from the U.S. Mortgage Default Crisis," Quarterly Journal of Economics 124, 1449-1496

Mian, A. R. and A. Sufi (2010), "House Prices, Home Equity-Based Borrowing, and the U.S. Household Leverage Crisis," American Economic Review, fortcoming

Morgan, D. P., B. Rime and P. E., Strahan (2004), "Bank Integration and State Business Cycles," Quarterly Journal of Economics, 119, 1555-1584

Moulton, B. R. (2010), "An Illustration of a Pitfall in Estimating the Effects of Aggregate Variables on Micro Units," Review of Economics and Statistics, 72, 334-338.

Petersen, M. (2009), "Estimating Standard Errors in Finance Panel Data Sets: Comparing Approaches," Review of Financial Studies, 22, 435-480.

Rice, T., and P. E. Strahan (2010), "Does Credit Competition Affect Small-Firm Finance," Journal of Finance, 65, 861-889. 
Saiz, A. (2010), "On Local Housing Supply Elasticity," Quarterly Journal of Economics forthcoming

Staiger, D., and J., Stock (1997), "Instrumental Variables Regression with Weak Instruments," Econometrica 65, 557-586.

Stiroh, K. J., and P. E. Strahan (2003), "Competitive Dynamics of Deregulation: Evidence from U.S. Banking," Journal of Money, Credit, and Banking, 35, 801-828.

Stock, J., J. Wright and M. Yogo (2002), "A Survey of Weak Instruments and Weak Identification in Generalized Method of Moments," Journal of Business and Economic Statistics, 20, 518-29. 
Figure 1. Full Sample of (1055) U.S. urban counties

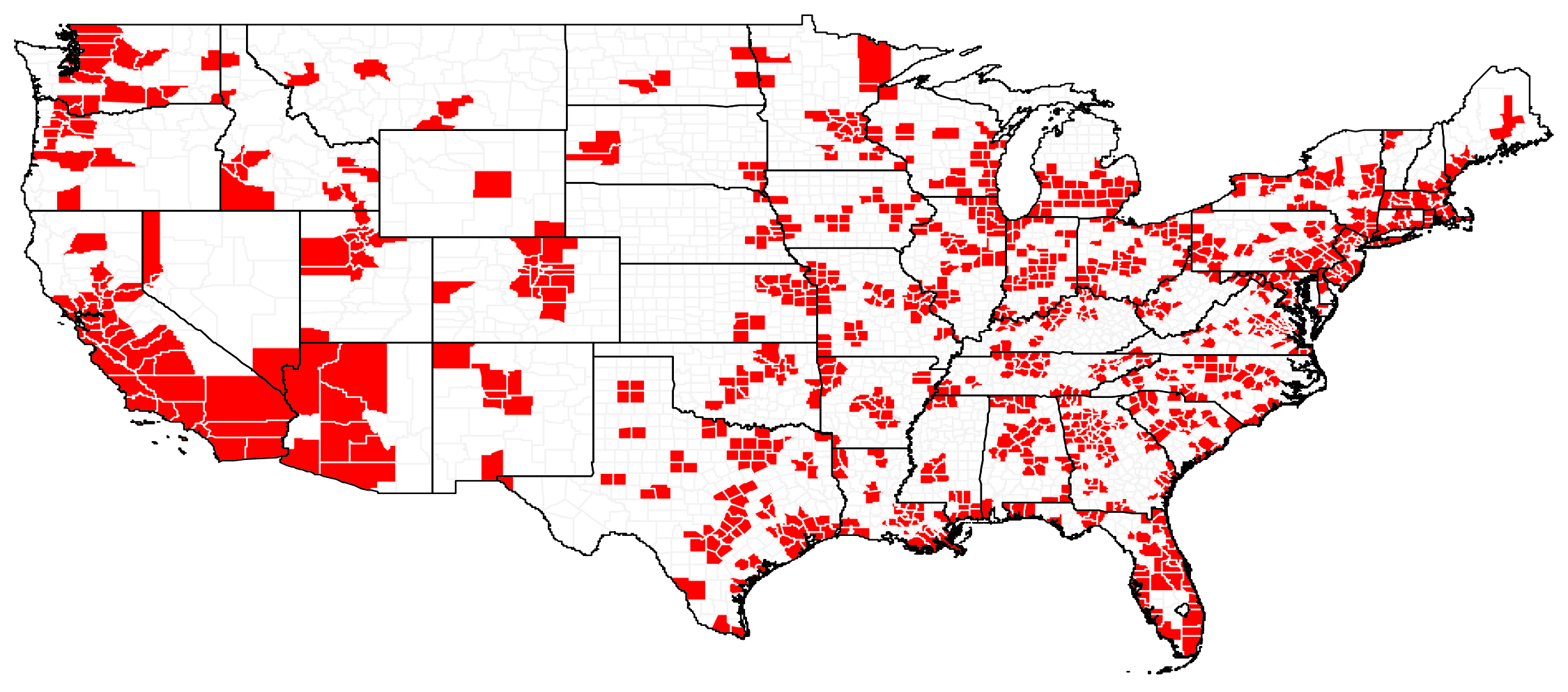


Figure 2. U.S. urban counties (248) in MSAs bordering two or more states

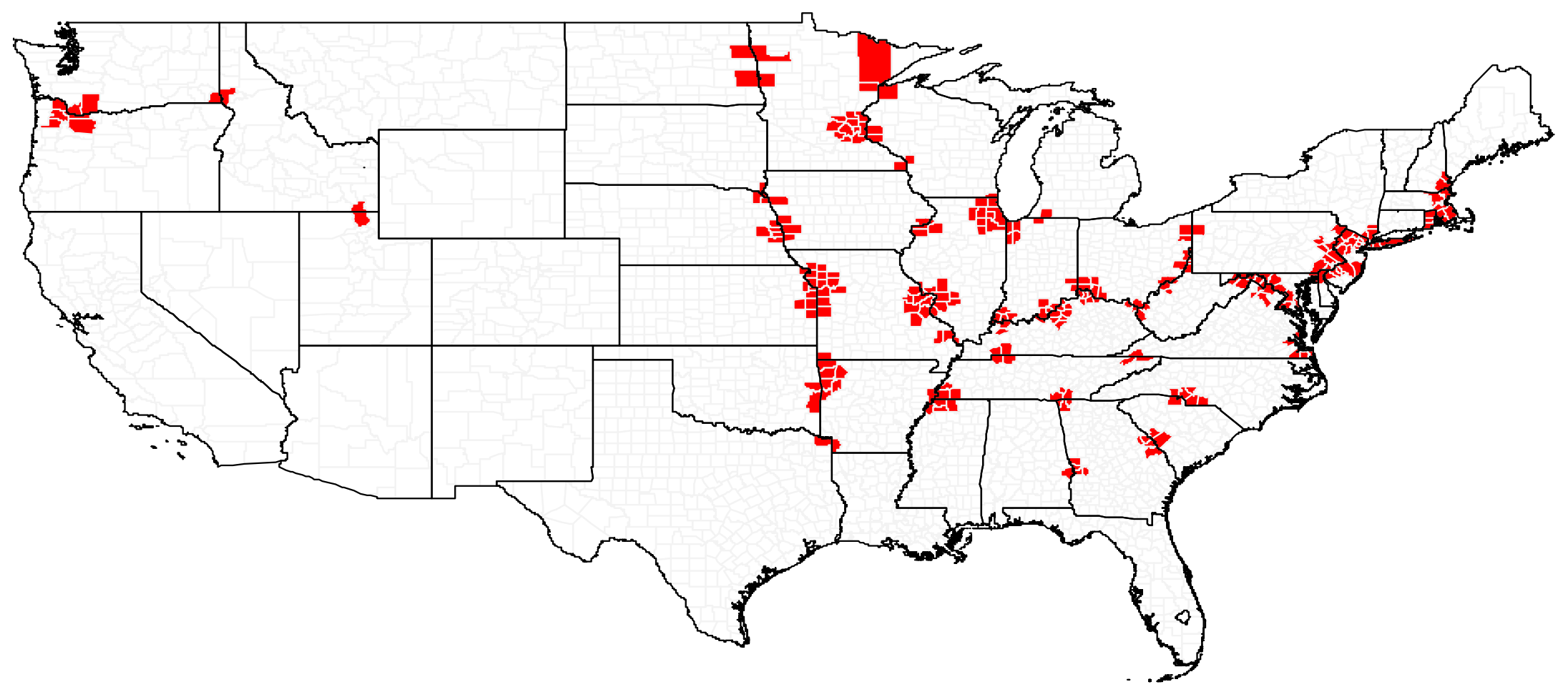


Table 1. Conventional and FHA insured loans by commercial banks and independent mortgage companies

Mean values of county-year pooled data for conventional (Panel A) and FHA (Federal Housing Administration) insured mortgage loans (Panel B). Loans are for purchase of single-familiy owner occupied houses. Lenders are commercial banks and independent mortgage companies. The sample includes 1055 US counties in urban areas for which mortgage data is available for the period 1993-2005

\begin{tabular}{|c|c|c|c|c|}
\hline & \multicolumn{4}{|c|}{ A.Conventional Loans } \\
\hline & $\begin{array}{c}\text { Full sample } \\
1993-2005\end{array}$ & 1995 & 2000 & 2005 \\
\hline & \multicolumn{4}{|c|}{ Number of Applications Received } \\
\hline & 980 & 531 & 1136 & 2340 \\
\hline \multirow[t]{2}{*}{ Independent mortgage companies } & 595 & 384 & 600 & 1348 \\
\hline & \multicolumn{4}{|c|}{ Number of Loans Originated } \\
\hline Commercial banks & 812 & 444 & 849 & 1968 \\
\hline \multirow[t]{2}{*}{ Independent mortgage companies } & 408 & 261 & 396 & 1026 \\
\hline & \multicolumn{4}{|c|}{ Average Loan Originated (thousand of dollars) } \\
\hline Commercial banks & 90 & 72 & 89 & 137 \\
\hline \multirow[t]{4}{*}{ Independent mortgage companies } & 78 & 56 & 80 & 112 \\
\hline & \multicolumn{4}{|c|}{ B. FHA Insured Loans } \\
\hline & $\begin{array}{c}\text { Full sample } \\
1993-2005\end{array}$ & 1995 & 2000 & 2005 \\
\hline & \multicolumn{4}{|c|}{ Number of Applications Received } \\
\hline Commercial banks & 158 & 116 & 189 & 95 \\
\hline \multirow[t]{2}{*}{ Independent mortgage companies } & 161 & 173 & 179 & 64 \\
\hline & \multicolumn{4}{|c|}{ Number of Loans originated } \\
\hline Commercial banks & 134 & 104 & 166 & 80 \\
\hline \multirow[t]{2}{*}{ Independent mortgage companies } & 144 & 158 & 155 & 56 \\
\hline & \multicolumn{4}{|c|}{ Average Loan Originated (thousand of dollars) } \\
\hline Commercial banks & 86 & 64 & 82 & 117 \\
\hline Independent mortgage companies & 85 & 67 & 79 & 112 \\
\hline
\end{tabular}


Table 2. Description of Variables and Data Sources

\begin{tabular}{|c|c|c|}
\hline Variable name & Variable description & Source \\
\hline $\begin{array}{l}\text { Index of interstate } \\
\text { branching deregulation }\end{array}$ & $\begin{array}{l}\text { Index of US interstate branching deregulation for commercial } \\
\text { banks based on no limits to: (1) de novo interstate branching, } \\
\text { (2) acquisition of individual branches, }(3) \text { statewide deposit cap } \\
\text { and, (4) minimum age of the target institution. The index ranges } \\
\text { from zero (most restrictive) to four (least restrictive). The index } \\
\text { is set to zero in 1993, the year before the passage of the } 1994 \\
\text { Interstate Banking and Branching Efficiency Act (IBBEA). }\end{array}$ & $\begin{array}{l}\text { Rice and Strahan } \\
(2010)\end{array}$ \\
\hline Number of loans & $\begin{array}{l}\text { Number of loans originated for purchase of single family owner } \\
\text { occupied houses. County level aggregation of loan level data. }\end{array}$ & HMDA \\
\hline Loan volume & $\begin{array}{l}\text { Dollar amount (in thousands of dollars) of loans originated for } \\
\text { purchase of single family owner occupied houses. County level } \\
\text { aggregation of loan level data. }\end{array}$ & HMDA \\
\hline Denial rate & $\begin{array}{l}\text { Number of loan applications denied divided by the number of } \\
\text { applications received. County level aggregation of loan level data. }\end{array}$ & HMDA \\
\hline Loan to income ratio & $\begin{array}{l}\text { Principal amount of loan originated (in thousands of dollars) for } \\
\text { purchase of single family owner occupied houses divided by total } \\
\text { gross annual applicant income (in thousands of dollars). County } \\
\text { level aggregation of loan level data. }\end{array}$ & HMDA \\
\hline $\begin{array}{l}\text { Fraction of originated } \\
\text { loans securitized }\end{array}$ & $\begin{array}{l}\text { Fraction of loans originated for purchase of single family owner } \\
\text { occupied houses sold within the year of origination to another non } \\
\text { affiliated financial institution or a government-sponsored housing } \\
\text { enterprise. County level aggregation of loan level data. }\end{array}$ & HMDA \\
\hline Herfindahl Index & $\begin{array}{l}\text { Sum of squared shares of mortgage loans. The shares are based } \\
\text { on the number of loans originated by a lender relative to the } \\
\text { total number of mortgage loans originated in a county. Loans are } \\
\text { for purchase of single family owner occupied houses. }\end{array}$ & HMDA \\
\hline House price index & $\begin{array}{l}\text { County median price of existing single-family homes, and Case- } \\
\text { Shiller-Weiss repeat sales index of existing single-family homes. }\end{array}$ & $\begin{array}{l}\text { Ecomony } \\
\text { Moody's.com }\end{array}$ \\
\hline $\begin{array}{l}\text { Housing supply } \\
\text { elasticity }\end{array}$ & Land-topology based measure of housing supply elasticity. & Saiz (2010) \\
\hline Income per capita & County personal income per capita. & BEA \\
\hline Population & County population (in thousands). & BEA \\
\hline
\end{tabular}


Table 3. Summary Statistics

Summary statistics of county-year pooled data. Except for the index of interstate branching deregulation and the index of housing supply elasticity, summary statistics refer to the annual log change of each variable during the period 1993-2005.

\begin{tabular}{|c|c|c|c|c|c|c|c|}
\hline & Mean & SD & $\begin{array}{l}\text { Between } \\
\text { SD }\end{array}$ & $\begin{array}{l}\text { Within } \\
\text { SD }\end{array}$ & 10 th pc & 90 th pc & $\begin{array}{c}\text { Number of } \\
\text { Counties/ } \\
\text { MSAs/States }\end{array}$ \\
\hline \multicolumn{8}{|l|}{ HMDA DATA -- county data } \\
\hline \multicolumn{8}{|l|}{ Commercial Banks } \\
\hline Number of loans & 0.1269 & 0.4941 & 0.1336 & 0.4760 & -0.2102 & 0.4264 & 1055 \\
\hline Loan Volume & 0.1820 & 0.5343 & 0.1422 & 0.5153 & -0.1693 & 0.5025 & 1055 \\
\hline Denial rate & -0.0300 & 0.3690 & 0.0557 & 0.3650 & -0.4602 & 0.3681 & 1055 \\
\hline Loan to income ratio & 0.0237 & 0.1390 & 0.0256 & 0.1368 & -0.0792 & 0.1220 & 1055 \\
\hline Fraction of originated loans securitized & 0.0400 & 0.3397 & 0.0706 & 0.3343 & -0.2671 & 0.3643 & 1055 \\
\hline $\begin{array}{l}\text { Herfindahl index of } \\
\text { bank concentration }\end{array}$ & -0.0447 & 0.3334 & 0.0739 & 0.3252 & -0.3978 & 0.2992 & 1055 \\
\hline \multicolumn{8}{|l|}{ Independent Mortgage Companies } \\
\hline Number of loans & 0.0861 & 0.3915 & 0.0726 & 0.3853 & -0.3567 & 0.5205 & 1055 \\
\hline Loan Volume & 0.1423 & 0.4191 & 0.0799 & 0.4120 & -0.3251 & 0.6039 & 1055 \\
\hline Denial rate & -0.0029 & 0.3099 & 0.0440 & 0.3069 & -0.3479 & 0.3335 & 1055 \\
\hline Loan to income ratio & 0.0251 & 0.1574 & 0.0259 & 0.1554 & -0.1162 & 0.1747 & 1055 \\
\hline Fraction of originated loans securitized & -0.0045 & 0.1930 & 0.0247 & 0.1915 & -0.1753 & 0.1660 & 1055 \\
\hline $\begin{array}{l}\text { Herfindahl index of } \\
\text { mortgage companies concentration }\end{array}$ & -0.1230 & 0.3663 & 0.0679 & 0.3605 & -0.5829 & 0.2974 & 1055 \\
\hline \multicolumn{8}{|l|}{ Commercial Banks -- prime lenders } \\
\hline Number of loans & 0.1240 & 0.4899 & 0.1321 & 0.4720 & -0.2124 & 0.4253 & 1055 \\
\hline Loan Volume & 0.1791 & 0.5283 & 0.1399 & 0.5097 & -0.1724 & 0.5044 & 1055 \\
\hline Denial rate & -0.0316 & 0.3813 & 0.0562 & 0.3774 & -0.4755 & 0.3721 & 1055 \\
\hline Loan to income ratio & 0.0236 & 0.1378 & 0.0247 & 0.1357 & -0.0797 & 0.1228 & 1055 \\
\hline Fraction of originated loans securitized & 0.0394 & 0.3412 & 0.0769 & 0.3357 & -0.2719 & 0.3639 & 1055 \\
\hline $\begin{array}{l}\text { Herfindahl index of } \\
\text { prime bank concentration }\end{array}$ & -0.0416 & 0.3335 & 0.0744 & 0.3251 & -0.3956 & 0.2985 & 1055 \\
\hline \multicolumn{8}{|l|}{ Coomercial Banks -- subprime lenders } \\
\hline Number of loans & 0.1869 & 1.1357 & 0.3818 & 1.1042 & -1.1708 & 1.6094 & 1023 \\
\hline Loan Volume & 0.2546 & 1.2065 & 0.4309 & 1.1709 & -1.1801 & 1.7377 & 1023 \\
\hline Denial rate & -0.0616 & 0.7595 & 0.2909 & 0.7368 & -0.9725 & 0.8473 & 1008 \\
\hline Loan to income ratio & 0.0334 & 0.5068 & 0.1909 & 0.4908 & -0.4930 & 0.5684 & 1023 \\
\hline Fraction of originated loans securitized & 0.0646 & 1.1449 & 0.3740 & 1.1142 & -1.2856 & 1.3863 & 882 \\
\hline $\begin{array}{l}\text { Herfindahl index of } \\
\text { subprime bank concentration }\end{array}$ & -0.0014 & 0.5024 & 0.1039 & 0.4973 & -0.6729 & 0.6931 & 1044 \\
\hline \multicolumn{8}{|l|}{ MOODY'S ECONOMY.COM -- county data } \\
\hline County median house price index & 0.0296 & 0.0459 & 0.0173 & 0.0426 & -0.0211 & 0.0809 & 1081 \\
\hline Case-Shiller-Weiss house price index & 0.0046 & 0.0887 & 0.0179 & 0.0868 & -0.0822 & 0.1072 & 358 \\
\hline \multicolumn{8}{|l|}{ BEA -- county data } \\
\hline Income per capita & 0.0139 & 0.0491 & 0.0134 & 0.0473 & -0.0156 & 0.0453 & 1081 \\
\hline Population & 0.0133 & 0.0162 & 0.0137 & 0.0087 & -0.0032 & 0.0342 & 1081 \\
\hline \multicolumn{8}{|l|}{ STRAHAN and RICE (2010) -- state data } \\
\hline Index of interstate branching deregulation & 1.2631 & 1.4791 & 1.0043 & 1.0863 & 0 & 4 & 51 \\
\hline \multicolumn{8}{|l|}{ SAIZ (2010) -- msa data } \\
\hline Index of housing supply elasticity & 2.4454 & 1.3416 & 1.3420 & 0.0000 & 0.9216967 & 3.992975 & 270 \\
\hline
\end{tabular}


Table 4. Interstate branching deregulation and loan decisions of commercial banks and independent mortgage companies

County level linear regressions of the log change in the Number of Mortgage Loans, Volume of Mortgage Loans, Mortgage Denial Rate, Loan to Income Ratio, and Fraction of Originated Loans Sold to another financial institution or a government-sponsored housing enterprise, on the Index of Interstate Branching Deregulation. Each regression includes the following controls: current and lagged log change in county's Income per capita, Population, House Price, and the Herfindahl Index for commercial banks or independent mortgage companies concentration. All variables are defined in Table 1. The sample includes all US counties in urban areas for which mortgage data is available for the period 1993-2005. Panel A reports regression results for mortgage loans originated by commercial banks. Panel B reports regression results for the placebo sample of mortgage loans originated by independent mortgage companies. The index of interstate branching deregulation ranges from 0 (most restricted) to 4 (least restricted). All regressions include county and year fixed effects. Standard errors are clustered by state. Estimates followed by ${ }^{* * *},{ }^{* *}$, and ${ }^{*}$ are statistically different from zero with $0.01,0.05$ and 0.10 significance levels, respectively.

\begin{tabular}{|c|c|c|c|c|c|}
\hline & \multicolumn{5}{|c|}{ A. Commercial Banks } \\
\hline & \multicolumn{5}{|c|}{ Dependent Variables } \\
\hline & $\begin{array}{c}\text { Number of } \\
\text { Loans }\end{array}$ & $\begin{array}{l}\text { Volume of } \\
\text { Loans }\end{array}$ & $\begin{array}{l}\text { Denial } \\
\text { Rate }\end{array}$ & $\begin{array}{c}\text { Loan to Income } \\
\text { Ratio }\end{array}$ & $\begin{array}{l}\text { Fraction of } \\
\text { Loans Sold }\end{array}$ \\
\hline $\begin{array}{l}\text { Index of interstate } \\
\text { branching deregulation }\end{array}$ & $\begin{array}{c}0.029^{* * *} \\
(0.010)\end{array}$ & $\begin{array}{c}0.030^{* * *} \\
(0.010)\end{array}$ & $\begin{array}{c}-0.034^{* * *} \\
(0.011)\end{array}$ & $\begin{array}{l}-0.000 \\
(0.001)\end{array}$ & $\begin{array}{c}0.001 \\
(0.008)\end{array}$ \\
\hline Observations & 11498 & 11498 & 11435 & 11498 & 11312 \\
\hline N. of counties & 1054 & 1054 & 1054 & 1054 & 1054 \\
\hline N. of MSAs & 359 & 359 & 359 & 359 & 359 \\
\hline N. of states & 51 & 51 & 51 & 51 & 51 \\
\hline \multirow[t]{4}{*}{ R2 within } & 0.174 & 0.151 & 0.183 & 0.075 & 0.062 \\
\hline & \multicolumn{5}{|c|}{ B. Independent Mortgage Companies } \\
\hline & \multicolumn{5}{|c|}{ Dependent Variables } \\
\hline & $\begin{array}{c}\text { Number of } \\
\text { Loans }\end{array}$ & $\begin{array}{l}\text { Volume of } \\
\text { Loans }\end{array}$ & $\begin{array}{l}\text { Denial } \\
\text { Rate }\end{array}$ & $\begin{array}{c}\text { Loan to Income } \\
\text { Ratio }\end{array}$ & $\begin{array}{l}\text { Fraction of } \\
\text { Loans Sold }\end{array}$ \\
\hline $\begin{array}{l}\text { Index of interstate } \\
\text { branching deregulation }\end{array}$ & $\begin{array}{l}-0.003 \\
(0.008)\end{array}$ & $\begin{array}{l}-0.003 \\
(0.008)\end{array}$ & $\begin{array}{c}0.000 \\
(0.005)\end{array}$ & $\begin{array}{c}0.001 \\
(0.003)\end{array}$ & $\begin{array}{c}0.000 \\
(0.003)\end{array}$ \\
\hline Observations & 11543 & 11543 & 11541 & 11543 & 11508 \\
\hline N. of counties & 1054 & 1054 & 1054 & 1054 & 1054 \\
\hline N. of MSAs & 359 & 359 & 359 & 359 & 359 \\
\hline N. of states & 51 & 51 & 51 & 51 & 51 \\
\hline R2 within & 0.232 & 0.190 & 0.227 & 0.075 & 0.044 \\
\hline
\end{tabular}


Table 5. Interstate branching deregulation and loan decisions of commercial banks and independent mortgage companies operating in counties within MSAs that straddle two or more US states

County level linear regressions of the log change in the Number of Mortgage Loans, Volume of Mortgage Loans, Mortgage Denial Rate, Loan to Income Ratio, and Fraction of Originated Loans Sold to another financial institution or a government-sponsored housing enterprise, on the Index of Interstate Branching Deregulation. Each regression includes the following controls: current and lagged log change in county's Income per capita, Population, House Price, and the Herfindahl Index for commercial banks or independent mortgage companies concentration. All variables are defined in Table 1. The sample includes all US counties in MSAs straddling two or more US states, and for which mortgage data is available for the period 1993-2005. Panel A reports regression results for mortgage loans originated by commercial banks. Panel B reports regression results for the placebo sample of mortgage loans originated by independent mortgage companies. The index of interstate branching deregulation ranges from 0 (most restricted) to 4 (least restricted). All regressions include county and year fixed effects. Standard errors are clustered at the state level and the border level. Estimates followed by ${ }^{* * *},{ }^{* *}$, and ${ }^{*}$ are statistically different from zero with $0.01,0.05$ and 0.10 significance levels, respectively.

\begin{tabular}{|c|c|c|c|c|c|}
\hline & \multicolumn{5}{|c|}{ A. Depository Banks } \\
\hline & \multicolumn{5}{|c|}{ Dependent Variables } \\
\hline & $\begin{array}{c}\text { Number of } \\
\text { Loans }\end{array}$ & $\begin{array}{l}\text { Volume of } \\
\text { Loans }\end{array}$ & $\begin{array}{c}\text { Denial } \\
\text { Rate }\end{array}$ & $\begin{array}{c}\text { Loan to Income } \\
\text { Ratio } \\
\end{array}$ & $\begin{array}{l}\text { Fraction of Loans } \\
\text { Sold } \\
\end{array}$ \\
\hline $\begin{array}{l}\text { Index of interstate } \\
\text { branching deregulation }\end{array}$ & $\begin{array}{c}0.032^{* *} \\
(0.012)\end{array}$ & $\begin{array}{c}0.030^{* *} \\
(0.013)\end{array}$ & $\begin{array}{c}-0.037^{* * *} \\
(0.012)\end{array}$ & $\begin{array}{c}-0.005^{* * *} \\
(0.002)\end{array}$ & $\begin{array}{c}0.005 \\
(0.012)\end{array}$ \\
\hline Observations & 3101 & 3101 & 3087 & 3101 & 3067 \\
\hline N. of counties & 284 & 284 & 284 & 284 & 284 \\
\hline N. of borders & 36 & 36 & 36 & 36 & 36 \\
\hline N. of states & 37 & 37 & 37 & 37 & 37 \\
\hline \multirow[t]{4}{*}{ R2 within } & 0.239 & 0.229 & 0.187 & 0.110 & 0.110 \\
\hline & \multicolumn{5}{|c|}{ B. Independent Mortgage Companies } \\
\hline & \multicolumn{5}{|c|}{ Dependent Variables } \\
\hline & $\begin{array}{c}\text { Number of } \\
\text { Loans }\end{array}$ & $\begin{array}{l}\text { Volume of } \\
\text { Loans }\end{array}$ & $\begin{array}{c}\text { Denial } \\
\text { Rate } \\
\end{array}$ & $\begin{array}{c}\text { Loan to Income } \\
\text { Ratio } \\
\end{array}$ & $\begin{array}{c}\text { Fraction of Loans } \\
\text { Sold }\end{array}$ \\
\hline $\begin{array}{l}\text { Index of interstate } \\
\text { branching deregulation }\end{array}$ & $\begin{array}{c}0.007 \\
(0.014)\end{array}$ & $\begin{array}{c}0.009 \\
(0.012)\end{array}$ & $\begin{array}{c}0.004 \\
(0.008)\end{array}$ & $\begin{array}{c}0.006 \\
(0.004)\end{array}$ & $\begin{array}{l}-0.001 \\
(0.006)\end{array}$ \\
\hline Observations & 3117 & 3117 & 3117 & 3117 & 3106 \\
\hline N. of counties & 284 & 284 & 284 & 284 & 284 \\
\hline N. of borders & 36 & 36 & 36 & 36 & 36 \\
\hline N. of states & 37 & 37 & 37 & 37 & 37 \\
\hline R2 within & 0.234 & 0.192 & 0.234 & 0.092 & 0.052 \\
\hline
\end{tabular}


Table 6 . Interstate branching deregulation and loan decisions of prime and subprime commercial banks operating in counties of MSAs that straddle two or more US states

County level linear regressions of the log change in the Number of Mortgage Loans, Volume of Mortgage Loans, Mortgage Denial Rate, Loan to Income Ratio, and Fraction of Originated Loans Sold to another financial institution or a government-sponsored housing enterprise, on the Index of Interstate Branching Deregulation. Each regression includes the following controls: current and lagged log change in county's Income per capita, Population, House Price, and the Herfindahl Index for prime or subprime commercial bank concentration. All variables are defined in Table 1. The sample includes all US counties in MSAs straddling two or more US states, and for which mortgage data is available for the period 1993-2005. Panel A report regression results for mortgage loans originated by non subprime commercial banks. Panel B reports regression results for subprime commercial banks. Subprime banks are identified using, for each year since 1993, the U.S. Department of Housing and Urban Development (HUD) list of commercial banks that specialize in subprime lending. The index of interstate branching deregulation ranges from 0 (most restricted) to 4 (least restricted). All regressions include county and year fixed effects. Standard errors are clustered at the state level and the border level. Estimates followed by $* * *, * *$, and $*$ are statistically different from zero with $0.01,0.05$ and 0.10 significance levels, respectively.

\section{A. Prime-Mortgage-Loan Commercial Banks}

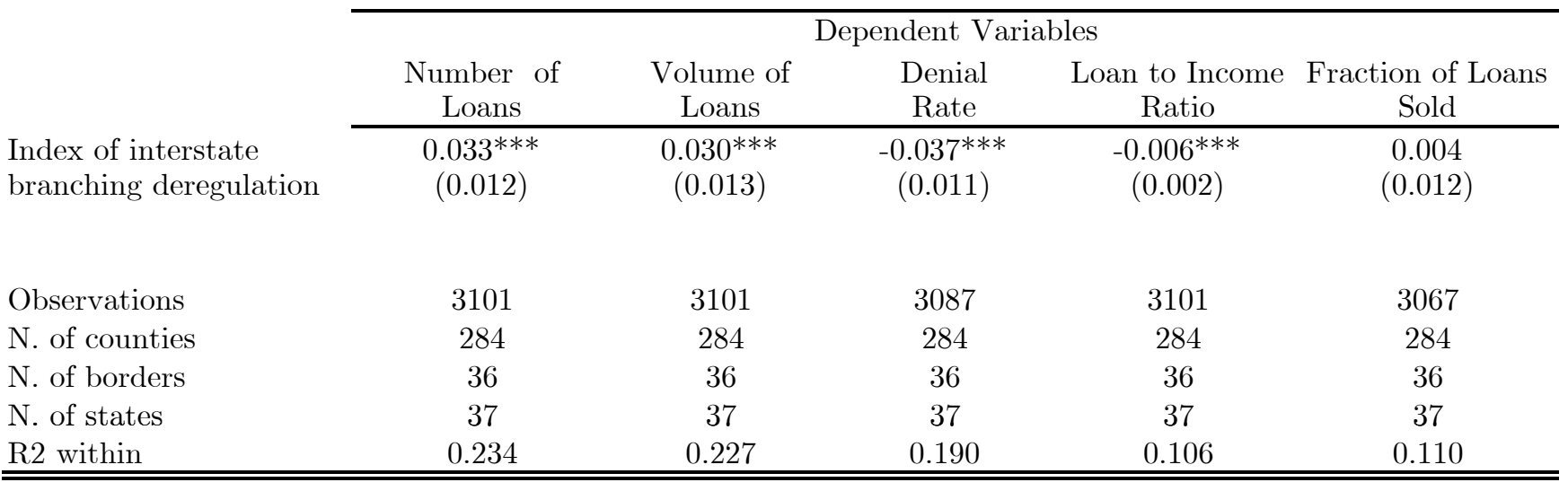

B. Subprime-Mortgage-Loan Commercial Banks

\begin{tabular}{|c|c|c|c|c|c|}
\hline \multirow[b]{3}{*}{$\begin{array}{l}\text { Index of interstate } \\
\text { branching deregulation }\end{array}$} & \multicolumn{5}{|c|}{ Dependent Variables } \\
\hline & $\begin{array}{c}\text { Number of } \\
\text { Loans }\end{array}$ & $\begin{array}{l}\text { Volume of } \\
\text { Loans }\end{array}$ & $\begin{array}{l}\text { Denial } \\
\text { Rate }\end{array}$ & $\begin{array}{c}\text { Loan to Income } \\
\text { Ratio }\end{array}$ & $\begin{array}{l}\text { Fraction of Loans } \\
\text { Sold }\end{array}$ \\
\hline & $\begin{array}{c}0.074 \\
(0.063)\end{array}$ & $\begin{array}{c}0.105 \\
(0.072)\end{array}$ & $\begin{array}{c}-0.108^{* * *} \\
(0.031)\end{array}$ & $\begin{array}{c}0.019 \\
(0.032)\end{array}$ & $\begin{array}{l}-0.014 \\
(0.065)\end{array}$ \\
\hline Observations & 1719 & 1791 & 1589 & 1791 & 1129 \\
\hline N. of counties & 275 & 275 & 275 & 275 & 275 \\
\hline N. of borders & 36 & 36 & 36 & 36 & 36 \\
\hline N. of states & 37 & 37 & 37 & 37 & 37 \\
\hline R2 within & 0.302 & 0.230 & 0.183 & 0.124 & 0.558 \\
\hline
\end{tabular}




\section{Tab 7. Interstate branching deregulation and house prices}

County level linear regressions of the log change in House Prices on the Index of Branching Deregulation. Control variables include the lagged log change in House Prices, the Elasticity of Housing Supply, the current and lagged log change in county Income per capita, and the current and lagged log change in county Population. All variables are defined in Table 1. In column (1) the sample includes all US counties in urban areas for which mortgage data is available for the period 1993-2005. In columns (2)-(4) the sample is limited to counties in MSAs for which Saiz (2010)'s measure of housing supply elasticity is available. The index of interstate branching deregulation ranges from 0 (most restricted) to 4 (least restricted). All regressions include county and year fixed effects. Standard errors are clustered by state. Estimates followed by $* * *, * *$, and $*$ are statistically different from zero with $0.01,0.05$ and 0.10 significance levels, respectively.

\begin{tabular}{|c|c|c|c|c|}
\hline \multirow[b]{3}{*}{ Index of interstate branching deregulation } & \multicolumn{4}{|c|}{$\begin{array}{c}\text { Dependent Variables } \\
\text { House Prices }\end{array}$} \\
\hline & (1) & $(2)$ & $(3)$ & (4) \\
\hline & $\begin{array}{c}0.001 \\
(0.003)\end{array}$ & $\begin{array}{c}0.000 \\
(0.003)\end{array}$ & $\begin{array}{c}0.014^{* * *} \\
(0.004)\end{array}$ & $\begin{array}{c}0.007^{* * *} \\
(0.003)\end{array}$ \\
\hline $\begin{array}{l}\text { Index of interstate branching deregulation } \times \\
\text { house supply elasticity }\end{array}$ & & & $\begin{array}{c}-0.006^{* * *} \\
(0.001)\end{array}$ & $\begin{array}{c}-0.004^{* * *} \\
(0.001)\end{array}$ \\
\hline Lagged house price & & & & $\begin{array}{c}0.487^{* * *} \\
(0.029)\end{array}$ \\
\hline Income per capita & & & & $\begin{array}{c}0.032 \\
(0.038)\end{array}$ \\
\hline Lagged income per capita & & & & $\begin{array}{c}0.106^{* * *} \\
(0.024)\end{array}$ \\
\hline Population & & & & $\begin{array}{c}0.453^{* * *} \\
(0.099)\end{array}$ \\
\hline Lagged Population & & & & $\begin{array}{c}0.295^{* * *} \\
(0.079)\end{array}$ \\
\hline Observations & 12646 & 10870 & 10870 & 9966 \\
\hline N. of counties & 1055 & 907 & 907 & 907 \\
\hline $\mathrm{N}$, of MSAs & 366 & 270 & 270 & 270 \\
\hline N. of states & 51 & 48 & 48 & 48 \\
\hline R2 within & 0.131 & 0.123 & 0.150 & 0.380 \\
\hline
\end{tabular}


Tab 8. Interstate branching deregulation and house prices in counties within MSAs that straddle two or more US states

County level linear regressions of the log change in House Prices on the Index of Branching Deregulation. Control variables include the lagged log change in House Prices, the Elasticity of Housing Supply, the current and lagged $\log$ change in county Income per capita, and the current and lagged log change in county Population. All variables are defined in Table 1. In column (1) the sample includes all US counties in MSAs straddling two or more US states, and for which mortgage data is available for the period 1993-2005. In columns (2)-(4) the sample is limited to counties in MSAs straddling two or more US states and for which Saiz (2010)'s measure of housing supply elasticity is available. The index of interstate branching deregulation ranges from 0 (most restricted) to 4 (least restricted). All regressions include county and year fixed effects. Standard errors are clustered at the state level and the border level. Estimates followed by ${ }^{* *},{ }^{* *}$, and $*$ are statistically different from zero with $0.01,0.05$ and 0.10 significance levels, respectively.

\begin{tabular}{|c|c|c|c|c|}
\hline \multirow[b]{3}{*}{ Index of interstate branching deregulation } & \multicolumn{4}{|c|}{$\begin{array}{c}\text { Dependent Variables } \\
\text { House Prices }\end{array}$} \\
\hline & (1) & $(2)$ & (3) & (4) \\
\hline & $\begin{array}{l}0.006^{*} \\
(0.003)\end{array}$ & $\begin{array}{l}0.006^{*} \\
(0.003)\end{array}$ & $\begin{array}{c}0.021^{* * *} \\
(0.007)\end{array}$ & $\begin{array}{c}0.012^{* * *} \\
(0.003)\end{array}$ \\
\hline $\begin{array}{l}\text { Index of interstate branching deregulation } \times \\
\text { house supply elasticity }\end{array}$ & & & $\begin{array}{c}-0.008^{* * *} \\
(0.003)\end{array}$ & $\begin{array}{c}-0.005^{* * *} \\
(0.001)\end{array}$ \\
\hline Lagged house price & & & & $\begin{array}{c}0.568^{* * *} \\
(0.065)\end{array}$ \\
\hline Income per capita & & & & $\begin{array}{c}0.153^{* * *} \\
(0.057)\end{array}$ \\
\hline Lagged income per capita & & & & $\begin{array}{c}0.075 \\
(0.057)\end{array}$ \\
\hline Population & & & & $\begin{array}{c}0.411^{* * *} \\
(0.126)\end{array}$ \\
\hline Lagged Population & & & & $\begin{array}{c}0.282 \\
(0.174)\end{array}$ \\
\hline Observations & 3528 & 3324 & 3324 & 3047 \\
\hline N. of counties & 294 & 277 & 277 & 277 \\
\hline N. of borders & 36 & 32 & 32 & 32 \\
\hline N. of states & 37 & 35 & 35 & 35 \\
\hline R2 within & 0.291 & 0.298 & 0.328 & 0.558 \\
\hline
\end{tabular}


Tab 9. Instrumental variable regressions for house prices in counties within MSAs that straddle two or more US states

Second stage county level linear regressions of an IV specification of the log change in House Prices on the Number of loans or the Loan volume or the Denial rate of commercial banks. Number of loans, Loan volume, and Denial rate are instrumented with the Index of Branching Deregulation. Control variables include the lagged log change in House Prices, the current and lagged log change in county Income per capita, and the current and lagged change in county Population. All variables are defined in Table 1 . The sample includes all US counties in MSAs straddling two or more US states, and for which mortgage data is available for the period 1993-2005. All regressions include county and year fixed effects. Standard errors are robust to heteroskedasticity and autocorrelation. Estimates followed by ${ }^{* * *},{ }^{* *}$, and $*$ are statistically different from zero with $0.01,0.05$ and 0.10 significance levels, respectively.

\begin{tabular}{|c|c|c|c|}
\hline \multirow[b]{3}{*}{ Instrumented Number of loans } & \multicolumn{3}{|c|}{$\begin{array}{c}\text { Dependent Variables } \\
\text { House Prices }\end{array}$} \\
\hline & (1) & $(2)$ & (3) \\
\hline & $\begin{array}{c}0.063^{* *} \\
(0.030)\end{array}$ & & \\
\hline Instrumented Loan volume & & $\begin{array}{c}0.068^{* *} \\
(0.034)\end{array}$ & \\
\hline Instrumented Denial rate & & & $\begin{array}{c}-0.052^{* *} \\
(0.023)\end{array}$ \\
\hline Lagged House price & $\begin{array}{c}0.553^{* * *} \\
(0.023)\end{array}$ & $\begin{array}{c}0.526^{* * *} \\
(0.030)\end{array}$ & $\begin{array}{c}0.587^{* * *} \\
(0.022)\end{array}$ \\
\hline Income per capita & $\begin{array}{c}0.060 \\
(0.048)\end{array}$ & $\begin{array}{c}0.050 \\
(0.053)\end{array}$ & $\begin{array}{c}0.090^{* *} \\
(0.040)\end{array}$ \\
\hline Lagged income per capita & $\begin{array}{l}0.061^{*} \\
(0.034)\end{array}$ & $\begin{array}{c}0.046 \\
(0.037)\end{array}$ & $\begin{array}{r}0.072^{* *} \\
(0.035)\end{array}$ \\
\hline Population & $\begin{array}{c}0.029 \\
(0.193)\end{array}$ & $\begin{array}{l}-0.007 \\
(0.229)\end{array}$ & $\begin{array}{l}0.246^{*} \\
(0.143)\end{array}$ \\
\hline Lagged Population & $\begin{array}{c}0.338^{* * *} \\
(0.125)\end{array}$ & $\begin{array}{l}0.260^{*} \\
(0.141)\end{array}$ & $\begin{array}{r}0.383^{* * *} \\
(0.123)\end{array}$ \\
\hline $\begin{array}{l}\text { First stage F-test of excluded instruments } \\
\text { (p value) }\end{array}$ & $\begin{array}{c}15.91 \\
(0.000)\end{array}$ & $\begin{array}{c}11.74 \\
(0.000)\end{array}$ & $\begin{array}{l}18.45 \\
(0.000)\end{array}$ \\
\hline Observations & 3101 & 3101 & 3087 \\
\hline N. of counties & 284 & 284 & 284 \\
\hline N. of borders & 36 & 36 & 36 \\
\hline N. of states & 37 & 37 & 37 \\
\hline
\end{tabular}


Tab 10. Interstate branching deregulation and the 2006-2008 house prices decline in counties within MSAs that straddle two or more US states

County level linear regressions of the log change in House Prices on the Index of Branching Deregulation. Columns (1) to (3) report cross county regression for the year 2006, 2007, 2008. Column (4) reports countyyear pooled regression for the period 2006-2008. Control variables include the lagged log change in House Prices, the Elasticity of Housing Supply, the current and lagged log change in county Income per capita, and the current and lagged log change in county Population. All variables are defined in Table 1. the sample includes all US counties in MSAs straddling two or more US states. The index of interstate branching deregulation is measured in 2005 and ranges from 0 (most restricted) to 4 (least restricted). The pooled regression in column (4) include year fixed effects. Standard errors are clustered at the state level and the border level. Estimates followed by ${ }^{* *},{ }^{* *}$, and $*$ are statistically different from zero with $0.01,0.05$ and 0.10 significance levels, respectively.

\begin{tabular}{|c|c|c|c|c|}
\hline & \multicolumn{4}{|c|}{$\begin{array}{c}\text { Dependent Variables } \\
\text { House Prices }\end{array}$} \\
\hline & $\begin{array}{c}1) \\
\text { CS 2006 }\end{array}$ & $\begin{array}{c}(2) \\
\text { CS 2007 }\end{array}$ & $\begin{array}{c}(3) \\
\text { CS 2008 }\end{array}$ & $\begin{array}{c}(4) \\
\text { Pooled } \\
2006-2008\end{array}$ \\
\hline Index of interstate branching deregulation & $\begin{array}{c}0.014 \\
(0.009)\end{array}$ & $\begin{array}{c}0.010^{* *} \\
(0.004)\end{array}$ & $\begin{array}{c}-0.017^{* *} \\
(0.008)\end{array}$ & $\begin{array}{c}-0.007^{* *} \\
(0.003)\end{array}$ \\
\hline $\begin{array}{l}\text { Index of interstate branching deregulation } \times \text { house } \\
\text { supply elasticity }\end{array}$ & $\begin{array}{c}-0.006^{*} \\
(0.003)\end{array}$ & $\begin{array}{l}-0.003 \\
(0.002)\end{array}$ & $\begin{array}{c}0.005^{* *} \\
(0.002)\end{array}$ & $\begin{array}{c}0.002 \\
(0.001)\end{array}$ \\
\hline Lagged house price & & & & $\begin{array}{c}0.453^{* * *} \\
(0.076)\end{array}$ \\
\hline Income per capita & $\begin{array}{c}0.040 \\
(0.190)\end{array}$ & $\begin{array}{l}-0.075 \\
(0.134)\end{array}$ & $\begin{array}{l}-0.049 \\
(0.206)\end{array}$ & $\begin{array}{c}0.110 \\
(0.093)\end{array}$ \\
\hline Lagged income per capita & & & & $\begin{array}{c}0.091 \\
(0.073)\end{array}$ \\
\hline Population & $\begin{array}{c}0.222 \\
(0.237)\end{array}$ & $\begin{array}{c}0.215 \\
(0.370)\end{array}$ & $\begin{array}{c}-0.991 \\
(0.679)\end{array}$ & $\begin{array}{c}0.077 \\
(0.180)\end{array}$ \\
\hline Lagged Population & & & & $\begin{array}{l}-0.179 \\
(0.194)\end{array}$ \\
\hline Observations & 271 & 271 & 271 & 813 \\
\hline N. of counties & 271 & 271 & 271 & 277 \\
\hline N. of borders & 32 & 32 & 32 & 32 \\
\hline N. of states & 35 & 35 & 35 & 35 \\
\hline R2 within & 0.141 & 0.093 & 0.142 & 0.631 \\
\hline
\end{tabular}

